\title{
Penerapan Supevisi Akademik Model Kunjungan Kelas untuk Meningkatkan Kinerja Guru dalam Proses Belajar Mengajar
}

\author{
Ninik Utami ${ }^{(1)}$ \\ ${ }^{1}$ SDN Sanankulon 3, Kabupaten Blitar, \\ Email: ${ }^{1}$ ninikutami7@gmail.com
}

\begin{abstract}
ABSTRAK
Kinerja guru di SDN Sanankulon $03 \mathrm{Kec}$. Sanankulon Kab.Blitar masih kurang .Melalui metode akademik model kunjungan kelas dapat meningkatkan kinerja guru dalam proses belajar mengajar. Hasil penelitian menunjukkan Siklus I keberhasilan guru daalam melaaksanakan proses belajar mengajar mencapai $75 \%$ atau ada 6 dari 8 guru yang sudah berhasil dalam melaksanakan proses belajar mengajar. Hasil tersebut menunjukkan bahwa pada sikus I secara klasikal ,guru belum berhasil hal ini disebabkan,karena guru yang memperoleh nilai $\geq 70$ hanya sebesar $75 \%$. Pencapaian keberhasilan ini lebih kecil dari persentase ketuntasan yang dikehendaki yaitu sebesar $85 \%$. Siklus II keberhasilan guru dalam melaksanakan proses belajar mengajar mencapai $100 \%$. Hasil tersebut menunjukkan bahwa pada siklus II secara klasikal, guru sudah berhasil. terbukti guru yang memperoleh nilai $\geq 70$ sudah mencapai ketentuan standarisasi yang dikehendaki yaitu $85 \%$.
\end{abstract}

Kata kunci: kinerja guru, supervisi akademik, kunjungan kelas,

\section{PENDAHULUAN}

Berdasarkan observasi awal, proses belajar mengajar di SDN Sanankulon 03 Kecamatan Sanankulon Kabupaten Blitar masih perlu ditingkatkan karena sebagian besar guru belum melakukan perencanaan yang matang sebelum melaksanakan kegiatan pembelajaran.

Berdasarkan keadaan tersebut di atas, maka diperlukan suatu mekanisme supervisi terhadap guru sebagai sentral dalam dunia pendidikan guna meningkatkan kinerjanya dalam proses belajar mengajar.

Kinerja Guru pada dasarnya merupakan kinerja atau unjuk kerja yang dilakukan oleh guru dalam melaksanakan tugasnya sebagai pendidik. Kualitas kinerja guru akan sangat menentukan pada kualitas hasil pendidikan, karena guru merupakan pihak yang paling banyak bersentuhan langsung dengan siswa dalam proses pendidikan/pembelajaran di lembaga pendidikan Sekolah.

Penilaian kinerja guru merupakan suatu proses yang bertujuan untuk mengetahui atau memahami tingkat kinerja guru satu dengan tingkat kinerja guru yang lainnya atau dibandingkan dengan standar yang telah ditetapkan. Handoko (1994: 135) menjelaskan bahwa penilaian prestai kerja (performance appraisal) adalah proses melalui mana organisasi-organisasi mengevaluasi atau menilai prestasi kerja karyawan

Penilaian kinerja guru memiliki manfaat bagi sebuah sekolah, karena dengan penilaian ini akan memberikan tingkat pencapaian dari standar, ukuran atau kriteria yang telah ditetapkan sekolah. Sehingga kelemahan-kelemahan yang terdapat dalam seorang guru dapat diatasi serta akan memberikan umpan balik kepada guru tersebut. Menurut Mangkupawira (2001: 224), manfaat dari penilaian kinerja karyawan adalah: (1) perbaikan kinerja; (2) penyesuaian kompensasi; (3) keputusan penetapan; (4) kebutuhan pelatihan dan pengembangan; (5) perencanaan dan pengembangan karir; (6) efisiensi proses penempatan staf; (7) ketidakakuratan informasi; (8) kesalahan rancangan pekerjaan; (9) kesempatan kerja yang sama; (10) tantangan-tantangan eksternal; (11) umpan balik pada SDM. 
Vol. 1 No. 1, Oktober 2017

Sedangkan Mulyasa (2007:157) menjelaskan tentang manfaat penilaian tenaga pendidikan Penilaian tenaga pendidikan biasanya difokuskan pada prestasi individu, dan peran sertanya dalam kegiatan sekolah.

Berdasarkan uraian di atas dapat dilihat bahwa penilaian kinerja penting dilakukan oleh suatu sekolah untuk perbaikan kinerja guru itu sendiri maupun untuk sekolah dalam hal menyusun kembali rencana atau strategi baru untuk mencapai tujuan pendidikan nasional.

Belajar merupakan hal yang kompleks. Kompleks belajar tersebut dapat dipandang dari dua subjek, yaitu dari siswa dan dari guru. Dari segi siswa, belajar dialami sebagai suatu proses. Siswa mengalami proses mental dalam menghadapi bahan belajar.

Abdillah dalam Aunnurrahman (2009:35) berpendapat, bahwa belajar adalah suatu usaha sadar yang dilakukan oleh individu dalam perubahan tingkah laku baik melalui latihan dan pengalaman yang menyangkut aspek aspek kognitif, afektif dan psikomotorik untuk memperoleh tujuan tertentu.

Syah (2010 : 87) berpendapat bahwa: belajar adalah tahapan perubahan seluruh tingkah laku individu yang relatif menetap sebagai hasil pengalaman dan interaksi dengan lingkungan melibatkan proses kognitif.

Sedangkan, Sudjana (2009:28) mengemukakan beberapa pendapatnya bahwa Belajar adalah suatu proses yang ditandai dengan adanya perubahan pada diri seseorang. Perubahan sebagai hasil proses belajar dapat ditunjukkan dalam berbagai bentuk seperti berubah pengetahuannya, pemahamannya, sikap dan tingkah lakunya, ketrampilannya, kecakapan dan kemampuannya, daya reaksinya, daya penerimaannya dan lain-lain aspek yang ada pada individu.

Hakim (2002 : 1) berpendapat bahwa belajar adalah suatu proses perubahan di dalam kepribadian manusia, dan perubahan tersebut ditampakkan dalam bentuk peningkatan kualitas dan kuantitas tingkah laku seperti peningkatan kecakapan, pengetahuan, sikap, kebiasaan, pemahaman, ketrampilan, daya pikir, dan lain-lain kemampuan. Sudjana (2009:29) menjelaskan bahwa Sama halnya belajar, mengajarpun pada hakikatnya adalah suatu proses mengatur, mengorganisasi lingkungan yang ada di sekitar siswa sehingga dapat menumbuhkan dan mendorong siswa melakukan proses belajar.

Pengertian supervisi menurut Purwanto (1995:76) supervisi ialah aktifitas pembinaan yang direncanakan untuk membantu para guru dan pegawai sekolah lainnya dalam melakukan pekerjaan mereka secara efektif. Supervisi akademik yang dilakukan kepala sekolah melalui pembinaan secara terprogram membantu guru untuk mengembangkan situasi belajar mengajar yang lebih baik dengan memecahkan masalah kegiatan belajar mengajar agar hasil yang dicapai bisa maksimal sehingga otomatis prestasi dan output lebih baik.

Kunjungan kelas untuk memperoleh gambaran tentang proses belajar mengajar dan pengelolaan kelas yang dilaksanakan guru. Pada waktu kunjungan kelas ini, supervisor dapat melihat hasil belajar siswa dan hal-hal yang menunjang dalam pelaksanaan kegiatan belajar mengajar menggunakan instrumen yang telah dipersiapkan.

\section{METODE \\ Tempat dan Waktu Penelitian}

Tempat yang digunakan dalam penelitian tindakan sekolah ini di SDN Sanankulon 03 Kecamatan Sanankulon Kabupaten Blitar. Penelitian ini dilakukan selama tiga bulan dari bulan Januari sampai dengan Maret 2016,

\section{Siklus Penelitian Tindakan Sekolah (PTS)}

Penelitian Tindakan Sekolah ini direncanakan dalam dua siklus, yaitu Siklus I dan Siklus II. Persiapan Penelitian Tindakan Sekolah (PTS) meliputi : (1) Rencana Pelaksanaan Pembelajaran (RPP). Merupakan perangkat pembelajaran sebagai 
pengembangan dari silabus dan digunakan sebagai pedoman guru dalam mengajar. Masing-masing RPP berisi standar kompetensi, kompetensi dasar, indikator pencapaian hasil belajar, materi pokok, media dan sumber belajar, soal instrumen, serta penilaian hasil belajar. (2) Lembar Observasi. Lembar observasi ini digunakan untuk membantu proses pengumpulan data yang terdiri dari aspek perencanaan mengajar, pelaksanaan mengajar, dan pemberian balikan.

\section{Subyek Penelitian}

Subyek penelitian adalah guru-guru yang ada di SDN Sanankulon 03 Kecamatan Sanankulon Kabupaten Blitar yang berjumlah 8 guru.

\section{Sumber Data}

Dalam penelitian ini penulis mengumpulkan data yang bersumber pada guruguru yang berjumlah 8 orang.

\section{Teknik Pengumpulan Data}

Teknik pengumpulan data yang penulis lakukan adalah dengan melakukan pengamatan sekaligus melakukan penilaian selama kegiatan supervisi berlangsung dalam setiap siklusnya. Pengamatan yang dikumpulkan berupa aktivitas guru dalam melakukan kegiatan proses belajar mengajar dengan mengedepankan tugas utama seorang guru yaitu melakukan perencanaan mengajar, melaksanakan pembelajaran, dan memberikan balikan.

\section{Indikator Kerja}

Penelitian ini dilaksanakan selama 2 siklus melalui supervisi akademik pada guru-guru di SDN Sanankulon 03 Kecamatan Sanankulon Kabupaten Blitar berjumlah 8 orang guru.

Tabel 1 Kriteria pengamatan aktivitas guru dalam melaksanakan proses pembelajaran

\begin{tabular}{|c|c|c|c|}
\hline No & Aspek yang diamati & Skor & Bobot \\
\hline 1. & $\begin{array}{l}\text { Perencanaan Pembelajaran } \\
\text { Apakah guru menyiapkan perencanaan sebelum } \\
\text { melaksanakan pembelajaran? } \\
\text { a. Merencanakan } \\
\text { b. Merencanakan tetapi kurang lengkap } \\
\text { c. Tidak merencanakan }\end{array}$ & $\begin{array}{l}3 \\
2 \\
1\end{array}$ & 3 \\
\hline 2. & $\begin{array}{l}\text { Pelaksanaan pembelajaran } \\
\text { Apakah guru melakukan proses pembelajaran } \\
\text { sesuai dengan perencanaan yang ada dalam } \\
\text { Rencana Pelaksanan Pembelajaran (RPP)? } \\
\text { a. Sesuai } \\
\text { b. Kurang sesuai } \\
\text { c. Tidak sesuai }\end{array}$ & $\begin{array}{l}4 \\
3 \\
1\end{array}$ & 4 \\
\hline 3. & $\begin{array}{l}\text { Pemberian Balikan } \\
\text { Apakah guru memberikan balikan terhadap } \\
\text { kegiatan pembelajaran yang telah dilakukan? } \\
\text { a. Memberikan balikan terhadap segala aspek } \\
\text { kegiatan pembelajaran } \\
\text { b. Hanya memberikan balikan terhdap materi } \\
\text { yang telah diajarkan } \\
\text { c. Tidak memberikan balikan }\end{array}$ & $\begin{array}{l}3 \\
2 \\
1\end{array}$ & 3 \\
\hline
\end{tabular}


Tabel 2. Lembar penilaian aktivitas guru dalam proses pembelajaran

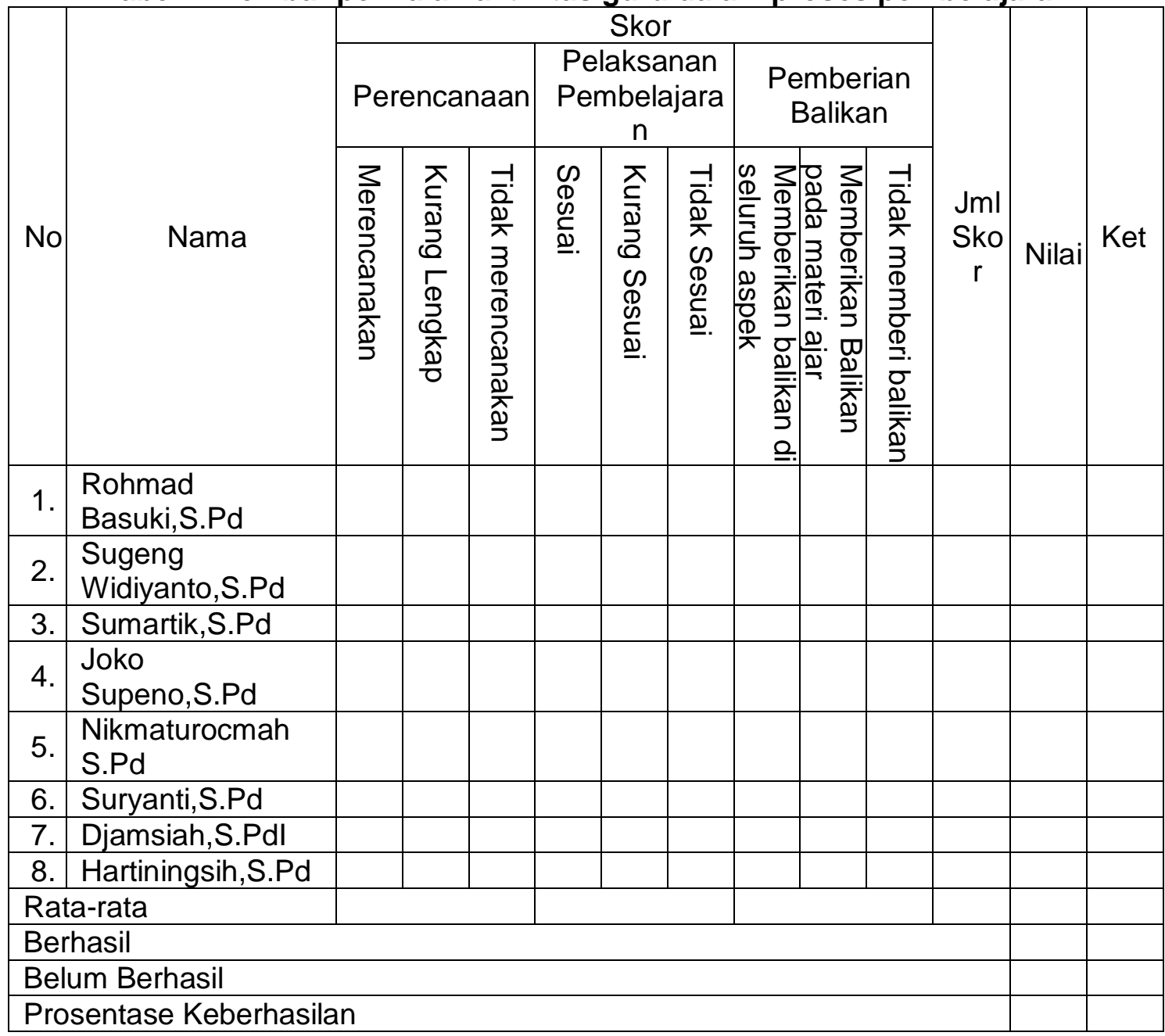

Dalam penelitian ini, penulis membuat sebuah standarisasi keberhasilan seorang guru dalam melaksanakan proses belajar mengajar apabila mencapai nilai $>=$ 70 , sedangkan untuk tingkat klasikal minimal mencapai $85 \%$.

\section{Tahapan Penelitian}

\section{Siklus I}

Perencanaan. Siklus I dilaksanakan pada tanggal 18-02-2016 dengan perencanaan meliputi Pertemuan dengan guru-guru, menginformasikan tentang pelaksanaan penelitian melalui supervisi akademik. Peneliti menyiapkan materi yang akan disajikan berkaitan dengan proses belajar mengajar dengan mengedepankan tugas utama guru. Peneliti menyiapkan instrumen penelitian (kriteria pengamatan dan penilaian aktivitas guru dalam melaksanakan proses belajar mengajar).

Pelaksanaan. Guru mempersiapkan perencanaan sebelum melakukan pembelajaran seperti kurikulum, program semester, silabus, RPP, materi pembelajaran, media pembelajaran, evaluasi, dan lembar penilaian. Guru melaksanakan proses pembelajaran dengan menggunakan metode pembelajaran sesuai RPP yang telah dibuat. Guru memberikan balikan terhadap kegiatan pembelajaran dengan memberikan penghargaan bagi siswa yang berprestasi sebagai motivasi untuk belajar. Kepala Sekolah selaku peneliti memberikan penguatan terhadap aktivitas guru dalam melaksanakan proses belajar mengajar.

Observasi Peneliti melakukan pengamatan pada guru terkait dengan aktivitas guru dalam melaksanakan proses belajar mengajar dengan mengedepankan tugas utama guru yaitu merencanakan, melaksanakan proses belajar mengajar, dan 
memberikan balikan. Peneliti memasukkan hasil pengamatan ke dalam lembar penilaian yang telah disediakan.

Refleksi. Refleksi dilakukan berdasarkan hasil pengamatan selama berlangsungnya aktivitas guru dalam melaksanakan proses belajar mengajar. Hasil refleksi ini dijadikan acuan untuk merencanakan penyempurnaan dan perbaikan siklus berikutnya.

\section{Siklus II}

Perencanaan. Pelaksanaan siklus II direncanakan pada tanggal 25-02-2016 dengan menggunakan tehnik supervisi akademik. Berdasarkan hasil observasi dan refleksi siklus I, dilakukan perbaikan terhadap strategi dan penyempurnaan pelaksanaan supervisi di siklus II.

Pelaksanaan. Kegiatan pada siklus II dilaksanakan dengan langkah-langkah sebagai berikut: Guru mendiskusikan tentang permasalahan-permasalan atau hambatan dalam melaksanakan proses belajar mengajar yang selanjutnya dicarikan pemecahannya. Peneliti sebagai kepala sekolah memberikan pengarahan kepada guru tentang perbaikan-perbaikan yang perlu dilakukan pada saat melaksanakan proses belajar mengajar. Sebagaimana pada siklus I, guru merencanakan, melaksanakan pembelajaran, dan memberikan balikan. Kepala Sekolah selaku peneliti memberikan penguatan tentang RPP yang telah dibuat guru. Kepala Sekolah selaku peneliti memberikan penguatan terhadap aktivitas guru dalam melaksanakan proses belajar mengajar. Pengawas selaku peneliti memberikan penghargaan bagi guru yang berhasil dalam melaksanakan proses belajar mengajar.

Observasi. Peneliti melakukan pengamatan pada guru terkait dengan aktivitas guru dalam melaksanakan proses belajar mengajar dengan mengedepankan tugas utama guru yaitu merencanakan, melaksanakan proses belajar mengajar, dan memberikan balikan. Peneliti memasukkan hasil pengamatan ke dalam lembar penilaian yang telah disediakan.

Refleksi. Berdasarkan hasil observasi selama berlangsungnya kegiatan dan hasil kinerja guru pada akhir pertemuan siklus II, maka dilanjutkan dengan mengadakan refleksi terhadap kegiatan dan hasil kegiatan yang sudah berlangsung.

\section{HASIL \\ Siklus I}

Kegiatan penelitian ini dilakukan dengan menggunakan teknis supervisi kunjungan kelas. Kepala Sekolah sebagai peneliti mengunjungi seluruh kelas untuk mengadakan penelitian terhadap pelaksanaan proses belajar mengajar kelas di SDN Sanankulon 03 Kecamatan Sanankulon Kabupaten Blitar.

\section{Perencanaan}

Siklus I dilaksanakan pada tanggal 18-02-2016 sampai 21-02-2016 dengan perencanaan meliputi Pertemuan dengan guru-guru, menginformasikan tentang pelaksanaan penelitian melalui supervisi akademik. Peneliti menyiapkan materi yang akan disajikan berkaitan dengan proses belajar mengajar dengan mengedepankan tugas utama guru. Peneliti menyiapkan instrumen penelitian (kriteria pengamatan dan penilaian aktivitas guru dalam melaksanakan proses belajar mengajar).

\section{Pelaksanaan Tindakan}

Pada kegiatan awal, peneliti selaku Kepala Sekolah memberi arahan umum tentang proses belajar mengajar dengan mengedepankan tugas utama guru yaitu merencanakan, melaksanakan, dan memberikan balikan.

Selanjutnya, guru memulai proses kegiatan belajar mengajar dengan mempersiapkan kurikulum, program tahunan, program semester, Rencana 
Vol. 1 No. 1, Oktober 2017

Pelaksanaan Pembelajaran, evaluasi, dan beberapa media guna mendukung proses belajar mengajar.

Guru memberikan appersepsi dengan memberikan beberapa pertanyaan terkait dengan indikator pembelajaran yang akan dicapai pada proses pembelajaran.

\section{Observasi}

Pada tahap ini dilakukan pengamatan sekaligus penilaian terhadap pelaksanaan kegiatan proses belajar mengajar yang dilakukan guru dengan menitik beratkan pada aspek perencanaan pembelajaran, pelaksanaan pembelajaran, dan pemberian balikan.

Dari hasil pengamatan terhadap aktivitas guru yang berjumlah 8 guru dengan menggunakan kriteria penilaian yang telah disiapkan, diperoleh data sebagai berikut

Tabel 3.Lembar penilaian aktivitas guru dalam proses belajar mengajar pada siklus I

\begin{tabular}{|c|c|c|c|c|c|c|c|c|c|c|c|c|c|}
\hline \multirow[b]{3}{*}{ No } & \multirow[b]{3}{*}{ Nama } & \multicolumn{9}{|c|}{ Skor } & \multirow[b]{3}{*}{$\begin{array}{c}\mathrm{Jml} \\
\text { Sko } \\
r\end{array}$} & \multirow[b]{3}{*}{ Nilai } & \multirow[b]{3}{*}{ Ket } \\
\hline & & \multicolumn{3}{|c|}{$\begin{array}{l}\text { Perenca } \\
\text { naan }\end{array}$} & \multicolumn{3}{|c|}{$\begin{array}{c}\text { Pelaksana } \\
n \\
\text { Pembelajar } \\
\text { an }\end{array}$} & \multicolumn{3}{|c|}{$\begin{array}{c}\text { Pemberian } \\
\text { Balikan }\end{array}$} & & & \\
\hline & & 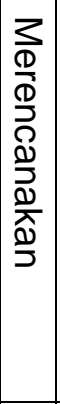 & 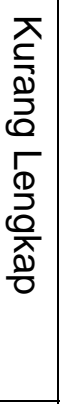 & 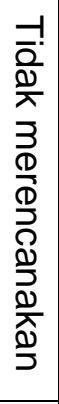 & 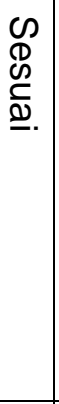 & 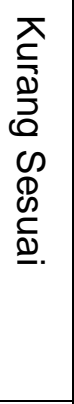 & 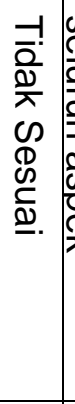 & 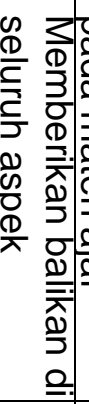 & 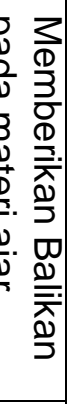 & 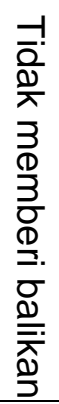 & & & \\
\hline 1. & $\begin{array}{l}\text { Rohmad } \\
\text { Basuki,S.Pd }\end{array}$ & 3 & & & & 3 & & & 2 & & 8 & 80 & $\begin{array}{l}\text { Berhasi } \\
\mathrm{I}\end{array}$ \\
\hline 2. & $\begin{array}{l}\text { Sugeng } \\
\text { Widiyanto,S.Pd, }\end{array}$ & 3 & & & & 3 & & & 2 & & 8 & 80 & $\begin{array}{l}\text { Berhasi } \\
\text { I }\end{array}$ \\
\hline 3. & Sumartik,S.Pd & 3 & & & & 3 & & & & 1 & 7 & 70 & Berhasi \\
\hline 4. & $\begin{array}{l}\text { Djoko } \\
\text { Supeno,S.Pd }\end{array}$ & & 2 & & & 3 & & & & 1 & 6 & 60 & Belum \\
\hline 5. & $\begin{array}{l}\text { Nikmaturocmah, } \\
\text { S.Pd }\end{array}$ & 3 & & & & 3 & & 3 & & & 9 & 90 & $\begin{array}{l}\text { Berhasi } \\
1\end{array}$ \\
\hline 6. & Suryanti,S.Pd & 3 & & & & 3 & & 3 & & & 9 & 90 & $\begin{array}{l}\text { Berhasi } \\
\text { I }\end{array}$ \\
\hline 7. & Djamsiah,S.Pd & 3 & & & & 3 & & & & 1 & 7 & 70 & Berhasi \\
\hline 8. & $\begin{array}{l}\text { Hartiningsih,S.P } \\
\mathrm{d}\end{array}$ & & 2 & & & 3 & & & & 1 & 6 & 60 & Belum \\
\hline Rata & -rata & & 3 & & & 3 & & & 2 & & & & \\
\hline Berr & asil & & & & & & & & & & & 6 & \\
\hline Belu & n Berhasil & & & & & & & & & & & 2 & \\
\hline Pros & entase Keberhasila & & & & & & & & & & & $75 \%$ & \\
\hline
\end{tabular}

Dari tabel diatas, dapat dijelaskan bahwa Secara klasikal, guru telah mempersiapkan berbagai perencanaan pembelajaran seperti kurikulum, program tahunan, program semester, silabus, dan Rencana Pelaksanaan Pembelajaran, dan evaluasi. 
Vol. 1 No. 1, Oktober 2017

Secara klasikal, guru kurang menyesuaikan pelaksanaan pembelajaran dengan Rencana Pelaksanaan Pembelajaran yang telah dibuat terutama pada pengelolaan alokasi waktu dan pemberian bimbingan pada saat siswa sedang berdiskusi.

Secara klasikal, guru sudah memberikan balikan terhadap materi ajar yang telah dipaparkan. Tetapi guru belum melakukan balikan terhadap proses kegiatan pembelajaran yang telah dilakukan. Selain itu guru juga belum memberikan penghargaan bagi kelompok yang berprestasi.

Dari tabel hasil penilaian di atas juga dapat dijelaskan bahwa dengan melakukan supervisi model kunjungan kelas yang ada di SDN Sanankulon 03 Kecamatan Sanankulon Kabupaten Blitar pada siklus I dalam melaksanakan proses belajar mengajar mencapai $75 \%$ atau ada 6 dari 8 guru sudah berhasil dalam melaksanakan proses belajar mengajar. Hasil tersebut menunjukkan bahwa pada siklus pertama secara klasikal, guru dikategorikan belum berhasil. Hal ini disebabkan karena guru yang memperoleh nilai $\geq 70$ hanya sebesar $75 \%$. Pencapaian keberhasilan ini lebih kecil dari persentase ketuntasan yang dikehendaki yaitu sebesar $85 \%$.

Dari hasil pengamatan dan penilaian tersebut di atas, Kepala Sekolah sebagai peneliti perlu melakukan beberapa hal sebagai berikut Peneliti perlu memberikan pemahaman kepada guru tentang pentingnya perencanaan pembelajaran, terutama penggunaan media pembelajaran guna mendukung efektifitas pembelajaran.

Peneliti perlu memberikan arahan kepada guru untuk selalu memberikan bimbingan dan motivasi belajar kepada siswa serta menyesuaikan pelaksanaan kegiatan pembelajaran dengan RPP yang telah dibuat.

Peneliti perlu memberikan pemahaman arti pentingnya memberikan balikan terhadap segala aspek dari seluruh kegiatan pembelajaran. Termasuk pemberian penghargaan bagi kelompok yang berprestasi.

\section{Refleksi}

Dalam pelaksanaan proses belajar mengajar pada siklus I diperoleh hasil sebagai berikut Secara klasikal, guru sudah melakukan perencanaan pembelajaran dengan baik dan benar. Secara klasikal, guru kurang menyesuaikan antara pelaksanaan pembelajaran dengan rencana pelaksanaan pembelajaran. Secara klasikal, guru telah memberikan balikan terhadap materi ajar yang telah dipaparkan, tetapi tidak memberikan balikan terhadap kegiatan pembelajaran yang telah dilakukan. Berdasarkan hasil pengamatan terlihat bahwa secara klasikal guru belum berhasil dalam proses belajar mengajar dan perlu dilakukan penelitian pada siklus II.

\section{Siklus II}

Kegiatan penelitian yang dilakukan pada siklus II sama dengan siklus I yaitu dengan menggunakan teknis supervisi kunjungan kelas. Kepala Sekolah sebagai peneliti mengunjungi seluruh untuk mengadakan penelitian terhadap pelaksanaan proses belajar mengajar kelas di SDN Sanankulon 03 Kecamatan Sanankulon Kabupaten Blitar.

\section{Perencanaan}

Siklus II dilaksanakan pada tanggal 25-02-2016 sampai dengan 28-02-2016 dengan perencanaan meliputi Pertemuan dengan guru-guru membahas tentang permasalahan-permasalahan yang dihadapi dalam proses kegiatan belajar mengajar. Peneliti menyiapkan materi yang akan disajikan untuk mengatasi permasalahanpermasalahan yang dihadapi guru-guru dalam proses kegiatan belajar mengajar. Peneliti menyiapkan instrumen penelitian berupa kriteria dan penilaian kinerja guru dalam proses kegiatan belajar mengajar. 


\section{Pelaksanaan Tindakan}

Pada kegiatan awal peneliti selaku Kepala Sekolah memberi arahan terhadap perbaikan-perbaikan yang perlu dibenahi dalam proses belajar mengajar baik tentang perencanaan, pelaksanaan pembelajaran, maupun pemberian balikan.

\section{Observasi}

Pada tahap ini dilakukan pengamatan sekaligus penilaian terhadap pelaksanaan kegiatan proses belajar mengajar yang dilakukan guru dengan menitik beratkan pada aspek perencanaan pembelajaran, pelaksanaan pembelajaran, dan pemberian umpan balik.

Dari hasil pengamatan terhadap aktivitas guru yang berjumlah 8 orang dengan menggunakan kriteria penilaian yang telah disiapkan, diperoleh data sebagai berikut

Tabel 5. Lembar penilaian aktivitas guru dalam proses belajar mengajar pada siklus II

\begin{tabular}{|c|c|c|c|c|c|c|c|c|c|c|c|c|c|}
\hline \multirow[b]{3}{*}{ No } & \multirow[b]{3}{*}{ Nama } & \multicolumn{9}{|c|}{ Skor } & \multirow[b]{3}{*}{$\begin{array}{l}\text { Jml } \\
\text { Sk } \\
\text { or }\end{array}$} & \multirow[b]{3}{*}{ Nilai } & \multirow[b]{3}{*}{ Ket } \\
\hline & & \multicolumn{3}{|c|}{$\begin{array}{c}\mathrm{Pe}- \\
\text { rencanaa } \\
\mathrm{n}\end{array}$} & \multicolumn{3}{|c|}{$\begin{array}{c}\text { Pelaksanan } \\
\text { Pembelajar } \\
\text { an }\end{array}$} & \multicolumn{3}{|c|}{$\begin{array}{l}\text { Pemberian } \\
\text { Balikan }\end{array}$} & & & \\
\hline & & 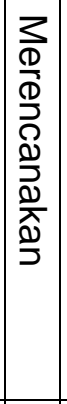 & 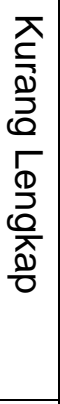 & 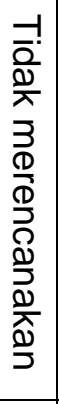 & 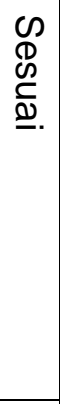 & 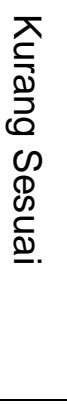 & 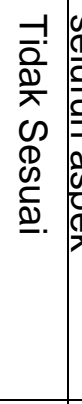 & 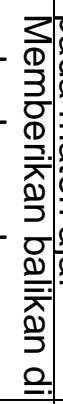 & 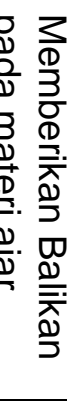 & 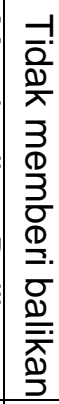 & & & \\
\hline 1. & $\begin{array}{l}\text { Rohmad } \\
\text { Basuki,,S.Pd }\end{array}$ & 3 & & & 4 & & & 3 & & & 10 & 100 & Berhasil \\
\hline 2. & $\begin{array}{l}\text { Sugeng } \\
\text { Widiyanto,S.Pd, }\end{array}$ & 3 & & & 4 & & & 3 & & & 10 & 100 & Berhasil \\
\hline 3. & Sumartik,S.Pd & 3 & & & & 3 & & & 2 & & 8 & 80 & Berhasil \\
\hline 4. & $\begin{array}{l}\text { SDjoko } \\
\text { Supeno,S.Pd }\end{array}$ & 3 & & & & 3 & & & 2 & & 8 & 80 & Berhasil \\
\hline 5. & $\begin{array}{l}\text { Nikmaturocmah, } \\
\text { S.Pd }\end{array}$ & 3 & & & 4 & & & 3 & & & 10 & 100 & Berhasil \\
\hline 6. & Suryanti,S.Pd & 3 & & & 4 & & & 3 & & & 10 & 100 & Berhasil \\
\hline 7. & Djamsiah,S.Pdl & 3 & & & & 3 & & & 2 & & 8 & 80 & Berhasil \\
\hline 8. & $\begin{array}{l}\text { Hartiningsih,S.P } \\
\text { d }\end{array}$ & 3 & & & & 3 & & & 2 & & 8 & 80 & Berhasil \\
\hline \multicolumn{2}{|c|}{ Rata-rata } & \multicolumn{3}{|c|}{3} & \multicolumn{3}{|c|}{4} & \multicolumn{3}{|c|}{3} & & & \\
\hline \multicolumn{11}{|c|}{ Berhasil } & & 8 & \\
\hline \multicolumn{11}{|c|}{ Belum Berhasil } & & 0 & \\
\hline \multicolumn{11}{|c|}{ Prosentase Keberhasilan } & & $\begin{array}{c}100 \\
\%\end{array}$ & \\
\hline
\end{tabular}

Dari tabel 5. diatas, dapat dijelaskan bahwa Secara klasikal, guru telah mempersiapkan berbagai perencanaan pembelajaran seperti kurikulum, program tahunan, program semester, silabus, dan Rencana Pelaksanaan Pembelajaran (RPP), dan evaluasi.

Secara klasikal, guru sudah menyesuaikan pelaksanaan pembelajaran dengan Rencana Pelaksanaan Pembelajaran yang telah dibuat. Guru telah 
memberikan bimbingan pada saat berdiskusi, sehingga ada interaksi antara siswa dan guru. Secara klasikal, guru sudah memberikan balikan di segala aspek kegiatan pembelajaran

\section{Refleksi}

Adanya peningkatan kinerja guru dalam mempersiapkan perencanaan pembelajaran. Adanya peningkatan kinerja guru dalam melaksanakan kegiatan pembelajaran baik pemberian appersepsi, motivasi, maupun bimbingan pada saat siswa berdiskusi. Adanya peningkatan kinerja guru dalam memberikan balikan terhadap semua aspek kegiatan pembelajaran. Secara klasikal penelitian dalam siklus II guru sudah berhasil dalam melaksanakan proses belajar mengajar

\section{PEMBAHASAN}

Berdasarkan hasil supervisi model kunjungan kelas yang ada di SDN Sanankulon 03 Kecamatan Sanankulon pada siklus I diperoleh keberhasilan guru dalam melaksanakan proses belajar mengajar mencapai $75 \%$ atau ada 6 dari 8 guru sudah berhasil dalam melaksanakan proses belajar mengajar. Hasil tersebut menunjukkan bahwa pada siklus pertama secara klasikal, guru belum berhasil. Hal ini disebabkan karena guru yang memperoleh nilai $\geq 70$ hanya sebesar $75 \%$. Pencapaian keberhasilan ini lebih kecil dari persentase ketuntasan yang dikehendaki yaitu sebesar $85 \%$.

Sedangkan pada siklus II diperoleh keberhasilan guru dalam melaksanakan proses belajar mengajar dengan mengedepankan tugas utama guru mencapai $100 \%$ atau semua guru sudah berhasil dalam melaksanakan proses belajar mengajar. Hasil tersebut menunjukkan bahwa pada siklus II secara klasikal, guru sudah berhasil. Hal ini disebabkan karena guru yang memperoleh nilai $\geq 70$ sudah mencapai ketentuan standarisasi yang dikehendaki yaitu $85 \%$. Sebagaimana tergambar dalam diagram batang berikut ini

\section{Grafik 1. Keberhasilan Guru}

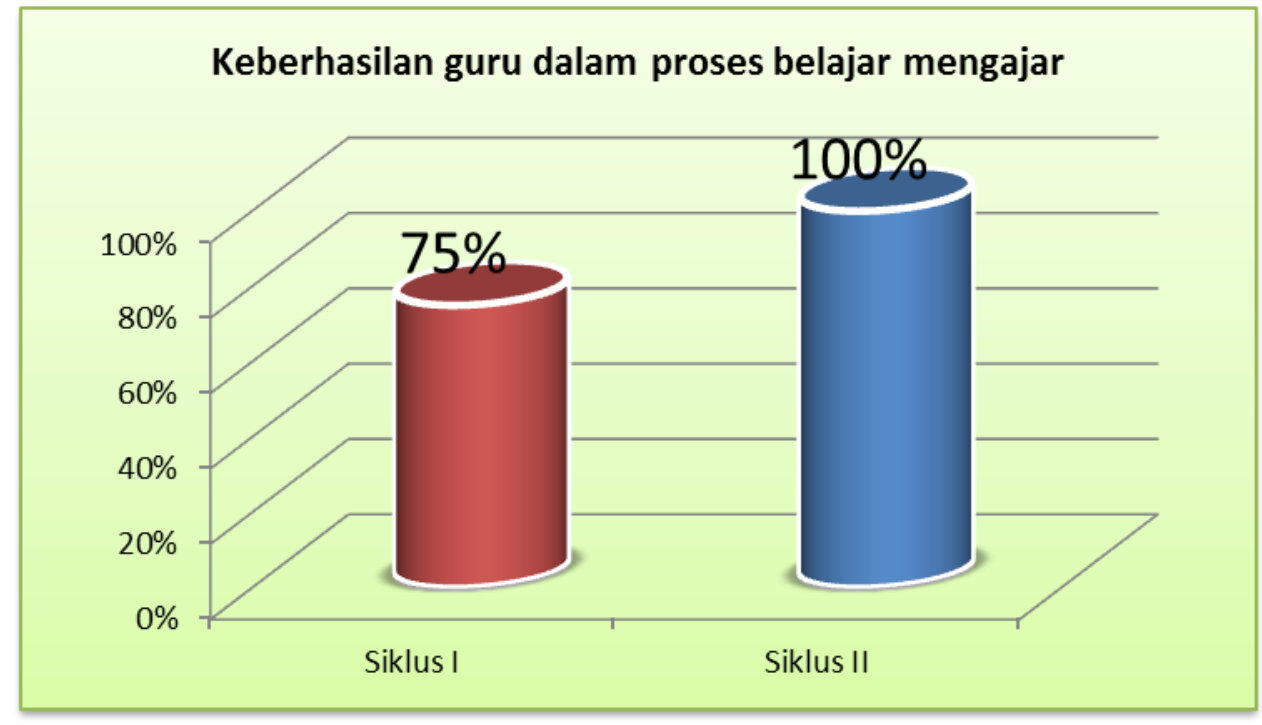

Berdasarkan hasil tersebut di atas menunjukkan bahwa supervisi model kunjungan kelas berdampak pada peningkatan kinerja guru SDN Sanankulon 03 Kecamatan Sanankulon Kabupaten Blitar dalam proses belajar mengajar.

\section{KESIMPULAN}

Berdasarkan hasil supervisi model kunjungan kelas yang ada di SDN Sanankulon 03 Kecamatan Sanankulon pada siklus I diperoleh keberhasilan guru dalam melaksanakan proses belajar mengajar dengan mengedepankan tugas utama 
guru mencapai $75 \%$ atau ada 6 dari 8 guru sudah berhasil dalam melaksanakan proses belajar mengajar. Hasil tersebut menunjukkan bahwa pada siklus pertama secara klasikal, guru belum berhasil. Hal ini disebabkan karena guru yang memperoleh nilai $\geq 70$ hanya sebesar $75 \%$. Pencapaian keberhasilan ini lebih kecil dari persentase ketuntasan yang dikehendaki yaitu sebesar $85 \%$.

Sedangkan pada siklus II diperoleh keberhasilan guru dalam melaksanakan proses belajar mengajar dengan mengedepankan tugas utama guru mencapai 100\% atau semua guru sudah berhasil dalam melaksanakan proses belajar mengajar. Hasil tersebut menunjukkan bahwa pada siklus II secara klasikal, guru sudah berhasil. Hal ini disebabkan karena guru yang memperoleh nilai $\geq 70$ sudah mencapai ketentuan standarisasi yang dikehendaki yaitu $85 \%$.

\section{SARAN}

Hendaknya guru melakukan perencanaan-perencanaan sebelum melaksanakan proses belajar mengajar. Dalam proses pelaksanaan pembelajaran, hendaknya guru melakukan inovasi dengan menggunakan strategi pembelajaran yang sesuai materi ajar. Selain itu guru perlu memberikan bimbingan-bimbingan pada saat siswa memecahkan permasalahan. Guru perlu memberikan balikan terhadap segala aspek dari kegiatan pembelajaran yang telah dilakukan. Kepala sekolah hendaknya memberikan motivasi guna meningkatkan kinerja guru dalam proses belajar mengajar. Membuat anggaran guna penyediaan sarana dan prasarana dalam meningkatkan mutu proses pembelajaran di sekolah. Kepala sekolah sebaiknya menjalin hubungan yang baik dengan guru sebagai mitra kerja bukan sebagai atasan dan bawahan.

\section{DAFTAR RUJUKAN}

Ali, M. 1987. Guru Dalam Proses Belajar Mengajar. Bandung: Sinar Baru.

Aunurrahman. 2009. Belajar dan Pembelajaran. Bandung: Alfabeta.

Darmadi, H. 2009. Kemampuan Dasar Mengajar. Bandung: Alfabeta.

Hakim, T. 2002. Belajar Secara Efektif. Jakarta: Puspa Swara.

Handoko, H. 1994. Manajemen (Edisi Kedua dan Ketiga). Yogyakarta : BPFE (Anggota IKAPI) Gadjah Mada Press.

Mulyasa, E. 2005. Menjadi Guru Profesional. Bandung: Remaja Rosdakarya.

Purwanto, N. 1995. Administrasi Dan Supervisi Pendidikan. Bandung: Rosdakarya.

Syah, M. Psikologi Pendidikan. Bandung: Remaja Rosdakarya.

Sudjana, N. 1990. Dasar-dasar Proses Belajar Mengajar. Bandung: Sinar Baru Algensindo.

Undang-Undang Republik Indonesia Nomor 20 Tahun 2003 tentang Sistem Pendidikan Nasional..

Undang-Undang No.14 Tahun 2005. tentang Guru dan Dosen. 